\title{
Pengaruh Kombinasi Guided Imagery dan Musik Klasik Terhadap Tingkat Kecemasan Mahasiswa Menjelang Objective Structured Clinical Examination (OSCE)
}

\author{
Yeni Nur Rahmayanti ${ }^{1}$, Dwi Surya Supriyana ${ }^{2 *}$, Yeni Ambarsari ${ }^{1}$ \\ 1.Program Studi Sarjana Keperawatan, STIKes Mitra Husada Karanganyar \\ 2. Bagian Akupunktur Medis, Rumah Sakit Pendidikan Universitas Sebelas Maret (UNS) \\ Korespondensi: 82dwisurya@gmail.com
}

\begin{abstract}
ABSTRAK
Pendahuluan: Objective Structured Clinical Examination (OSCE) merupakan metode untuk menguji kompetensi klinik secara obyektif dan terstruktur dalam bentuk putaran station dengan waktu tertentu. OSCE memunculkan perasaan takut, tegang, gelisah, sulit berkonsentrasi dan gangguan pencernaan pada mahasiswa. Guided Imagery yang dipadukan dengan intrumen musik klasik merupakan salah satu cara mengurangi kecemasan. Penelitian ini bertujuan untuk mengetahui pengaruh Guided Imagery terhadap tingkat kecemasan mahasiswa menjelang OSCE.

Metode: Penelitian ini merupakan penelitian eksperimental kuasi dengan pretest-posttest control group design. Sampel penelitian adalah seluruh mahasiswa aktif semester pertama (angkatan 2019) Prodi Sarjana Keperawatan STIKes Mitra Husada Karanganyar sejumlah 32 orang dengan kriteria belum pernah mendapatkan terapi relaksasi Guided Imagery dan baru pertama kali menempuh OSCE. Teknik sampling yang digunakan adalah purposive sampling. Subjek penelitian dibagi menjadi dua kelompok, yakni kelompok perlakuan dan kelompok kontrol. Kelompok perlakuan mendapatkan terapi kombinasi guided imagery dengan musik klasik selama 5 hari berturut-turut menjelang waktu pelaksanaan OSCE dengan durasi waktu 20 menit. Pengaruh guided imagery terhadap tingkat kecemasan dianalisis menggunakan uji statistik $t$ independent.

Hasil: Hasil penelitian menunjukan terdapat perbedaan rata-rata antara tingkat kecemasan

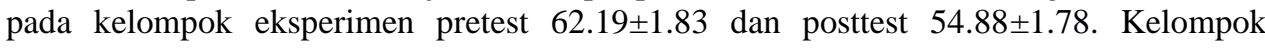
kontrol rata-rata pretest $62.50 \pm 2.22$ dan posttest $63.00 \pm 1.93$. Nilai p (CI 95\%) $<0.05$ $(\mathrm{p}=0.00)$ yang menunjukkan adanya pengaruh signifikan Guided Imagery terhadap penurunan tingkat kecemasan.

Kesimpulan: Terdapat pengaruh siginifikan pemberian kombinasi guided imagery dengan musik klasik terhadap penurunan tingkat kecemasan mahasiswa semester pertama program studi keperawatan menjelang OSCE.
\end{abstract}

Kata kunci: guided imagery; tingkat kecemasan; OSCE

\begin{abstract}
Introduction: Objective Structured Clinical Examination (OSCE) is a method to test clinical competence in an objective and structured manner in the form of a station rotation with a certain time. OSCE raises feelings of fear, tension, anxiety, difficulty concentrating, and indigestion in students. Guided Imagery combined with classical music instruments is one way to reduce anxiety. This study aims to determine the effect of Guided Imagery on students' anxiety levels before OSCE.

Methods: This study was a quasi-experimental study with pretest-posttest control group design. Subjects were all in the first semester active nursing students (batch 2019) of the Undergraduate Nursing Study Program of STIKes Mitra Husada Karanganyar, totaling 32
\end{abstract}


people with the criteria that they have never received Guided Imagery relaxation therapy, and this was the first time taking OSCE. The sampling technique used was purposive sampling. The research subjects were divided into two groups, namely the treatment group and the control group. The treatment group received combined guided imagery therapy with classical music for five consecutive days before the OSCE implementation time with a duration of twenty minutes. The effect of guided imagery on anxiety levels was analyzed using the tindependent statistical test.

Result: The results showed that there was an average difference between the level of anxiety in the experimental group pretest $62.19 \pm 1.83$ and posttest $54.88 \pm 1.78$. The control group had an average of $62.50 \pm 2.22$ pretest and $63.00 \pm 1.93$ posttest. The $p$ value (CI 95\%) $<0.05(p=0.00)$, which indicates that Guided Imagery has a significant effect on reducing anxiety levels.

Conclusion: There is a significant effect of providing a combination of guided imagery with classical music to reduce students's anxiety level in first semester of nursing study programs before OSCE.

Keywords: guided imagery; anxiety level; OSCE

\section{LATAR BELAKANG}

Kecemasan adalah salah satu masalah kesehatan jiwa yang masih sering terjadi pada masyarakat Indonesia ${ }^{1}$ Kecemasan merupakan reaksi alami normal yang dapat terjadi pada setiap orang di setiap tahapan kehidupannya sebagai respon peringatan. Reaksi tersebut dapat berupa rasa takut yang tidak jelas disertai dengan perasaan ketidakpastian, ketidakberdayaan, isolasi, dan ketidakamanan. Namun, reaksi cemas yang terjadi secara berlebihan dan tak terkendali akan menjadi masalah serius dan dapat mempengaruhi kondisi fisik individu ${ }^{1,2}$. Banyak pendapat yang menyatakan faktorfaktor penyebab terjadinya kecemasan, diantaranya dipengaruhi oleh faktor internal (dari dalam individu) yang meliputi kondisi jasmani dan rohani mahasiswa, dan faktor eksternal (dari luar individu) yang meliputi faktor lingkungan. Kecemasan sebesar $75 \%$ muncul pada usia 11 tahun sampai dengan 21 tahun $^{2}$.

Kecemasan pada sebagian besar mahasiswa dapat terpicu saat menjalani ujian $^{3,4}$. Ujian merupakan suatu rangkaian persoalan, pertanyaan-pertanyaan, dan latihan untuk menentukan tingkat pengetahuan, kemampuan, kualifikasi atau kompetensi peserta didik ${ }^{4}$. Situasi ujian yang memerlukan suatu keterampilan dengan penilaian standar yang tinggi dan bersifat kompetisi akan meningkatkan kecemasan serta mengganggu individu untuk fokus terhadap hal-hal yang perlu dilakukan. Kecemasan ujian (test anxiety) memunculkan ketakutan dan kekhawatiran terhadap situasi yang mengevaluasi keterampilan terutama berkaitan dengan bidang akademik ${ }^{5}$. Salah satu jenis format ujian yang sangat terkait dengan kecemasan yaitu $\mathrm{OSCE}^{6}$.

\section{Objective Structured Clinical}

Examination (OSCE) adalah bentuk uji yang digunakan sebagai ujian formatif dan sumatif untuk menilai kompetensi keterampilan di berbagai disiplin ilmu baik kedokteran, keperawatan dan farmasi ${ }^{7}$, dan sebagai sumber belajar serta alat untuk mengidentifikasi kesenjangan dan kelemahan dalam komunikasi dan keterampilan klinik. Sembilan puluh persen mahasiswa merasa OSCE adalah peristiwa yang penuh tekanan (stressful $)^{8}$. OSCE juga dianggap mahasiswa menjadi ujian yang memiliki stresor lebih dibandingkan dengan jenis ujian lainnya, terlebih pada mahasiswa yang baru pertama kali menempuh ujian OSCE di semester awal perkuliahan ${ }^{9}$.

Menurut Yang et al, penelitianpenelitian yang terkait, ada beberapa faktor 
yang dapat mempengaruhi terjadinya kecemasan pada mahasiswa saat menghadapi ujian ketrampilan. Faktor-faktor tersebut antara lain adalah sikap pengawas ujian (observer), suasana lingkungan ujian, ketrampilan mahasiswa, ujian, dan perasaan internal yang dirasakan oleh mahasiswa yang bersangkutan seperti perasaan khawatir selama proses ujian atau perasaan tidak yakin kalau akan lulus ujian ketrampilan ${ }^{10}$.

Pengaruh positif OSCE terhadap kepercayaan diri mahasiswa sebesar $97.1 \%$, ketrampilan saat ujian OSCE sebesar $98.8 \%$, pengetahuan terhadap teori sebesar $97.7 \%$, sedangkan ketrampilan terhadap motivasi perawat $97.1 \%{ }^{11}$. Menurut Oranye et al, ada penelitian yang memvalidasi kebutuhan OSCE, baik dalam desain program gelar keperawatan tersier dan penilaian tingkat kompetensi klinis perawat menunjukkan bahwa pada responden perawat dengan pengalaman lebih dari 10 tahun di bidang keperawatan dan kualitifikasi dasar didapatkan $14 \%$ perawat memiliki kompetensi level empat, yang menunjukkan bahwa mereka dapat melakukan tugas dengan benar dan selesai. Namun, 12\% gagal di OSCE. Reliabilitas antar penilai adalah 0.92 untuk lima penguji. Analisis faktor menunjukkan bahwa lima faktor peserta menyumbang $74.1 \%$ dari variasi klinis kinerja keterampilan ${ }^{12}$. Tingkat kecemasan yang dialami masing-masing individu ketika menghadapi ujian adalah berbeda-beda sehingga dibutuhkan suatu indikator untuk mengukur kecemasan yang dialami seseorang, salah satunya dengan menggunakan kuesioner Hamilton Rating Scale for Anxiety (HRS-A). HRS-A mengelompokkan tingkat kecemasan menjadi lima tingkatan, yaitu tidak ada kecemasan, kecemasan ringan, kecemasan sedang, kecemasan berat, dan kecemasan berat sekali. Alat ukur lainnya adalah Nursing Skills Test Anxiety Scale (NSTAS) yang berjumlah 6 (enam) item pertanyaan yang telah terbukti memiliki validitas critical ration nya $(\mathrm{CR}>4)$ 9.58-17.74 dan reliabilitas 0.77. 10,13

Cara sederhana dan efektif untuk mengelola gejala kecemasan atau stres adalah melalui teknik relaksasi, salah satunya adalah Guided Imagery. Guided imagery merupakan suatu teknik relaksasi nonfarmakologis yang mudah dan sederhana, bermanfaat untuk menurunkan kecemasan/ stres, mengurangi ketegangan tubuh atau kontraksi otot, dan memfasilitasi tidur dan dapat membantu untuk lebih mengakses kebijaksanaan batin seseorang ${ }^{14}$. Luís dan Kolcaba menjelaskan guided imagery membantu melawan pikiran yang kaku, otomatis, dan putus asa. Pengertian ini membantu memperkuat harga diri dan transendensi pribadi. Harga diri dan transendensi memberikan kontribusi pada pengalaman yang lebih positif. Imajinasi menciptakan jembatan antara pikiran dan tubuh, menghubungkan persepsi, emosi, dan respon psikologis, fisiologis, dan perilaku ${ }^{15}$. Kombinasi guided imagery dengan musik klasik adalah teknik yang telah banyak terbukti memiliki efek signifikan dalam mengatasi stres ${ }^{15,16}$.

Penelitian tentang penggunaan guided imagery maupun kombinasi dengan musik sebagai penatalaksanaan nonfarmakologis untuk kecemasan telah banyak dilakukan oleh peneliti-peneliti sebelumnya terutama untuk menangani pasien-pasien di rumah sakit, demikian pula untuk penelitian tingkat kecemasan pada mahasiswa dalam menghadapi ujian, termasuk OSCE. Namun, memberikan intervensi kombinasi guided imagery dengan musik pada mahasiswa yang menghadapi ujian OSCE untuk mengatasi kecemasannya dan kemudian dibandingkan dengan yang tidak diberikan intervensi masih jarang dilakukan.

Berdasarkan dari uraian tersebut di atas, penelitian ini berusaha untuk mengetahui lebih lanjut mengenai efek dari kombinasi guided imagery dan musik klasik dalam menurunkan tingkat kecemasan pada 
mahasiswa semester awal yang menempuh OSCE di program studi keperawatan.

\section{METODE PENELITIAN}

Penelitian ini merupakan penelitian eksperimental quasi dengan pretest-posttest with control group design. Penelitian ini dilakukan di STIKes Mitra Husada Karanganyar pada Program Studi Sarjana Keperawatan, Karanganyar, Jawa Tengah, Indonesia pada bulan Januari 2020.

Subjek penelitian adalah seluruh mahasiswa aktif semester pertama (angkatan 2019) dari program studi Sarjana Keperawatan dengan kriteria belum pernah mendapatkan terapi relaksasi kombinasi Guided Imagery dan musik klasik dan baru pertama kali menempuh OSCE. Teknik sampling yang digunakan adalah purposive sampling. Total subjek penelitian adalah sejumlah 32 orang mahasiswa. Subjek kemudian dibagi menjadi dua kelompok dengan cara pengacakan (simple random sampling). Kelompok pertama mendapatkan perlakuan berupa kombinasi guided imagery dengan musik klasik yang diberikan selama lima hari berturut-turut dengan durasi pemberian 20 menit menjelang pelaksanaan OSCE. Responden kelompok perlakuan dikumpulkan di sebuah ruangan yang tenang dengan dilengkapi peralatan soundsystem yang dihubungkan dengan headset untuk masing-masing orang. Responden dipandu untuk mendengarkan musik klasik menggunakan headset, diminta memejamkan mata, membayangkan pemandangan, dan merelaksasikan otot-ototnya. Sedangkan, kelompok kedua sebagai kontrol tidak diberikan perlakuan.

Tingkat kecemasan diukur menggunakan kuesioner Nursing Skills Test Anxiety Scale (NSTAS) versi Bahasa Indonesia yang telah dimodifikasi, terdiri dari 20 (dua puluh) butir item pertanyaan yang telah dilakukan uji validitas muka pada ahli.
Kuesioner diberikan kepada kedua kelompok sebelum dan sesudah perlakuan (pre and posttest). Perbedaan rata-rata tingkat kecemasan pretest dan posttest pada kedua kelompok dianalisis menggunakan Paired $t$ test, dan untuk mengetahui perbedaan kedua kelompok dianalisis menggunakan Independen T-test dengan tingkat kemaknaan $\alpha=0.05$.

\section{HASIL}

Subjek penelitian ini adalah seluruh mahasiswa aktif semester pertama (angkatan 2019) Program Studi Sarjana Keperawatan STIKes Mitra Husada Karanganyar yang baru pertama kali akan menempuh ujian OSCE sejumlah 32 orang. Tidak ada subjek penelitian yang drop out. Berikut ini adalah karakteristik responden penelitian yang tersaji dalam tabel 1:

Tabel 1. Karakteristik Responden Penelitian

\begin{tabular}{ccc}
\hline $\begin{array}{c}\text { Karakteristik } \\
\text { Responden }\end{array}$ & $\begin{array}{c}\text { Kelompok } \\
\text { Perlakuan } \\
(\mathrm{n}=16)\end{array}$ & $\begin{array}{c}\text { Kelompok } \\
\text { Kontrol } \\
(\mathrm{n}=16)\end{array}$ \\
\hline $\begin{array}{l}\text { Rata-rata usia } \\
\text { (mean } \pm \text { SD })\end{array}$ & $19.00 \pm 1.03$ & $18.75 \pm 0.68$ \\
$\begin{array}{c}\text { Jenis kelamin } \\
\text { Laki-laki }\end{array}$ & $7(22 \%)$ & $0(0 \%)$ \\
$\begin{array}{c}\text { Perempuan } \\
\text { Tingkat }\end{array}$ & $9(28 \%)$ & $16(50 \%)$ \\
kecemasan & & \\
Pretest & & \\
Normal & 0 & 0 \\
Ringan & 0 & 0 \\
Sedang & 16 & 16 \\
Berat & 0 & 0 \\
Posttest & 0 & 0 \\
Normal & 0 & 0 \\
Ringan & 16 & 16 \\
Sedang & 0 & 0 \\
Berat & 0 &
\end{tabular}

Jenis kelamin subjek penelitian ini adalah 7 orang laki-laki (22\%) dan 25 orang perempuan $(78 \%)$ dengan pendistribusian frekuensi pada masing-masing kelompok tersaji dalam tabel 1 . Rerata umur pasien pada kelompok perlakuan adalah 19 tahun 
sedangkan kelompok kontrol 18.75 tahun. Tingkat kecemasan menjelang OSCE pada saat pretest (sebelum diberikan perlakuan), kedua kelompok memiliki tingkat kecemasan sedang (100\%). Pada saat posttest (setelah kelompok pertama mendapat perlakuan), tingkat kecemasan seluruh responden pada kelompok perlakuan adalah ringan (16 orang), sedangkan pada kelompok kedua (kontrol) adalah tetap (kecemasan sedang).

Perbedaan rata-rata tingkat kecemasan pretest dan posttest pada kedua kelompok dianalisis menggunakan Paired t test tersaji dalam tabel 2 berikut ini:

Tabel 2. Perbedaan rata-rata skor tingkat kecemasan pretest dan postest

\begin{tabular}{lcc}
\hline \multicolumn{1}{c}{ Kelompok } & Mean \pm SD & $\begin{array}{c}\text { Nilai p } \\
(\text { CI95\%) }\end{array}$ \\
\hline Eksperimen $(\mathrm{n}=16)$ & & \\
$\quad$ Pretest & $62.19 \pm 1.83$ & $0.00^{*}$ \\
$\quad$ Posttest & $54.88 \pm 1.78$ & \\
Kontrol $(\mathrm{n}=16)$ & & \\
$\quad$ Pretest & $62.50 \pm 2.22$ & $0.46^{*}$ \\
$\quad$ Posttest & $63.00 \pm 1.93$ & \\
\hline *Paired t test & &
\end{tabular}

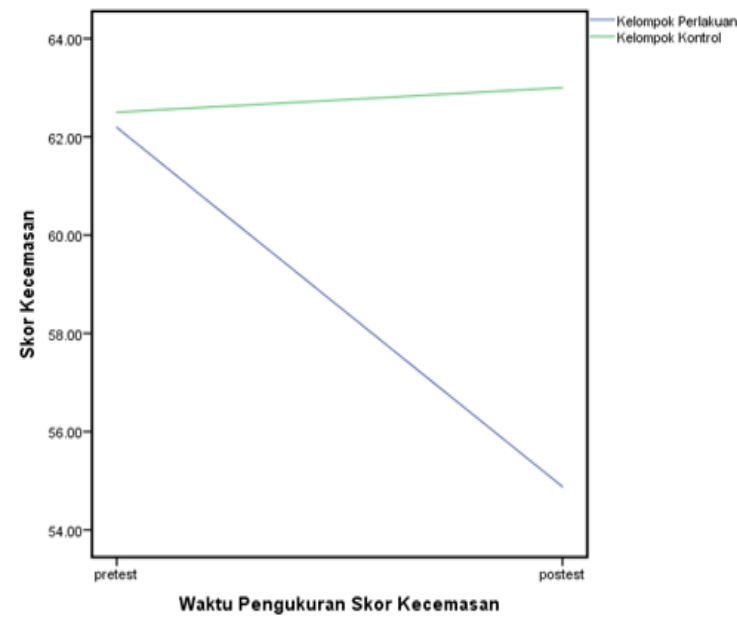

Gambar 1. Grafik Garis Skala Kecemasan pre and posttest dari kelompok perlakuan dan kontrol

Pengaruh terapi kombinasi guided imagery dan musik klasik terhadap tingkat kecemasan mahasiswa keperawatan semester pertama menjelang OSCE dianalisis menggunakan Uji Independen $T$ Test dengan hasil nilai $\mathrm{p}<0.05(\mathrm{p}=0.00)$ yang berarti terdapat pengaruh signifikan kombinasi guided imagery dengan musik klasik terhadap tingkat kecemasan mahasiswa keperawatan semester I menjelang OSCE.

Berikut adalah diagram garis yang menunjukkan adanya penurunan skor kecemasan pada kelompok perlakuan yang mendapatkan terapi guided imagery:

\section{PEMBAHASAN}

Hasil penelitian berdasarkan distribusi tingkat kecemasan sebelum dilakukan terapi kombinasi guided imagery dan musik klasik didapatkan rata-rata pada kelompok eksperimen dengan tingkat kecemasan adalah 62.19 dengan semua responden sejumlah 16 orang mempunyai tingkat kecemasan sedang. Demikian pula, rata-rata tingkat kecemasan kelompok kontrol sebelum dilakukan terapi kombinasi guided imagery dan musik klasik adalah 62.50 dengan responden 16 orang yang masing-masing mempunyai tingkat kecemasan sedang.

Hal tersebut di atas sesuai dengan teori kecemasan yang dialami oleh individu, biasanya terjadi disebabkan oleh beberapa faktor yang mempengaruhi, baik secara internal maupun eksternal ${ }^{1,2}$. Penelitian ini menunjukkan bahwa banyak seluruh mahasiswa yang akan menempuh ujian OSCE pertama kalinya mengalami tingkat kecemasan dalam rentang cemas sedang.

Hasil penelitian ini berbeda dengan penelitian yang dilakukan oleh Putri Amir et al (2016) yang menjelaskan bahwa tidak ada mahasiswa Falkutas Kedokteran Universitas Andalas yang mengalami kecemasan dalam menghadapi OSCE. ${ }^{4}$

Tidak didapatkan perbedaan signifikan tingkat kecemasan (pretest dan posttest) pada kelompok kontrol selama lima hari persiapan menjelang OSCE. Sedangkan, pada kelompok eksperimen yang diberikan kombinasi guided 
imagery dengan musik klasik selama lima hari berturut-turut dengan durasi 20 menit menjelang OSCE didapatkan perbedaan yang signifikan dari tingkat kecemasannya sebelum dan sesudah perlakuan diberikan.

Penelitian ini sejalan dengan penelitian Kaur et al yang memberikan guided imagery kepada 100 orang mahasiswa keperawatan tingkat pertama di DMCH College of Nursing and Institute of Nursing Education Guru Teg Bahadur Sahib Hospital, Ludhiana. Hasil penelitiannya menunjukkan bahwa pada kelompok perlakuan, skor kecemasannya lebih rendah setelah mendapatkan terapi kombinasi guided imagery dan musik klasik dibandingkan kelompok kontrol ${ }^{17}$.

Guided imagery yang diberikan kepada pasien-pasien di rumah sakit juga memberikan hasil yang serupa pada tingkat kecemasan. Kolcaba menuliskan artikel penelitian eksperimental kuasi yang menjelaskan kemanjuran intervensi guided imagery untuk mengurangi depresi, kecemasan, dan stres serta meningkatkan kenyamanan pada pasien rawat inap psikiatri dengan gangguan depresi. Enam puluh pasien depresif rawat inap jangka pendek dipilih secara berurutan. Kelompok eksperimen yang mendapatkan guided imagery selama 10 hari berturut-turut. Seluruh responden mengisi kuesioner DASS 21 (Depression, Anxiety, and Stress Scale) dan hasil analisis menunjukkan bahwa kelompok perlakuan secara signifikan meningkat rasa kenyamanannya, yang berarti depresi, kecemasan, dan stres berkurang dengan pemberian guided imagery ${ }^{15}$.

Perbedaan tingkat kecemasan kelompok eksperimen pada pretest dan posttest dianalisis menggunakan uji Independen $t$ Test yang menunjukkan nilai $\mathrm{p}<0.05(\mathrm{p}=0.00)$. Hal ini menunjukkan bahwa guided imagery dapat menurunkan kecemasan mahasiswa keperawatan semester pertama sebelum dan sesudah dilakukan terapi kombinasi guided imagery dan musik klasik sebelum menghadapi OSCE.
Hasil penelitian ini sejalan dengan penelitian Pietra yang menunjukkan adanya penurunan tingkat kecemasan siswa-siswi yang mendapatkan paparan musik. Pemberian guided imagery menggunakan terapi musik klasik berdampak terhadap penurunan tingkat kecemasan pada mahasiswa yang menghadapi ujian OSCE ${ }^{18}$.

Banyak cara yang dapat digunakan untuk menangani kecemasan dengan teknik kombinasi guided imagery dan musik. Hawari mengatakan bahwa relaksasi, makan coklat, tidur dapat memulihkan segala keletihan fisik dan mental. Selain itu, penanganan kecemasan dapat dilakukan dengan mendengarkan musik. Terapi musik termasuk salah satu penanganan dalam menangani stres dan kecemasan ${ }^{19,20}$. Pemberian terapi musik klasik membuat seseorang menjadi rileks, menimbulkan rasa aman dan sejahtera, dan menurunkan tingkat kecemasan $^{21}$.

Pemberian guided imagery memiliki konsekuensi fisiologis yang mendalam, dan tubuh cenderung merespons pencitraan sebagaimana adanya akan menjadi pengalaman eksternal yang asli. Misalnya, jika seseorang membayangkan dengan jelas menghisap seiris lemon segar, asam, dan berair, orang tersebut akan segera mulai mengeluarkan air liur. Guided imagery terbukti memengaruhi hampir semua sistem fisiologis utama tubuh, termasuk pernapasan, detak jantung, tekanan darah, laju metabolisme dalam sel, mobilitas dan sekresi gastrointestinal, fungsi seksual, kadar kortisol, lipid darah, dan bahkan daya imunitas tubuh. Guided imagery berhubungan dengan perubahan fisiologis spesifik yang dapat meningkatkan penyembuhan sehingga terapi relaksasi ini merupakan alternatif penting untuk kondisi medis yang memerlukan farmakoterapi dengan keamanan yang jauh lebih besar dan komplikasi yang jauh lebih minimal. Kombinasi guided imagery dan musik klasik menekan rasa kecemasan melalui penciptaan rasa nyaman dan rileks 
yang disertai dengan imajinasi positif sehingga dapat merangsang meningkatnya endorfin dalam tubuh dan menurunkan ACTH (Adreno Cortico Tropic Hormone). Peningkatan endorfin dan penurunan ACTH ini menyebabkan hormon kortisol menurun dan tingkat kecemasan menjadi turun ${ }^{14}$.

\section{KESIMPULAN}

Kombinasi guided imagery dan musik klasik secara signifikan menurunkan tingkat kecemasan pada mahasiswa keperawatan semester I menjelang OSCE.

\section{UCAPAN TERIMA KASIH}

Penulis menyampaikan terimakasih kepada ibu Eka Novitayanti, S. Kep., Ns., M. Kep. selaku Ketua Program Studi Sarjana Keperawatan STIKes Mitra Husada Karanganyar atas ijinnya untuk dapat melaksanakan penelitian ini, dan kepada ibu dr. Arsita Eka Prasetyawati, M. Kes atas motivasinya untuk dapat tersusunnya artikel ini.

\section{DAFTAR PUSTAKA}

1. Malfasari E, Devita Y, Erlin F, Filer F. Faktor-faktor yang mempengaruhi kecemasan mahasiswa dalam menyelesaikan tugas akhir di STIKes Payung Negeri Pekanbaru. J Ners Indones., [internet] 2019;9(1):124.

2. Utami TW, Astuti YS, PH L. Hubungan kecemasan dengan depresi pada anak Sekolah Dasar. $J$ keperawatan stikes Kendal., [internet] 2017;9(1):1-5.

3. Risma GB. Kecemasan dalam Objective Structured Clinical Examination (OSCE). Agromed Unila., [internet] 2015;2(4):419424.

4. Putri Amir D, Iryani D, Isrona L. Hubungan tingkat kecemasan dalam menghadapi Objective Structured Clinical Examination (OSCE) dengan kelulusan OSCE pada mahasiswa Fakultas Kedokteran Universitas Andalas. $J$ Kesehat Andalas.[internet] 2016;5(1):139-144.

5. Brown LA, Forman EM, Herbert JD, Hoffman KL, Yuen EK, Goetter EM. A randomized controlled trial of acceptancebased behavior therapy and cognitive therapy for test anxiety: A pilot study. Behav Modif., [internet] 2011;35(1):31-53.

6. Alghifari MM, Hartono, Randhita ABT. Studi kualitatif kecemasan pada mahasiswa kedokteran saat menghadapi Objective Structured Clinical Examination (OSCE). Nexus Pendidik Kedokt dan Kesehat., [internet] 2016;5(2):145-160.

7. Mårtensson G, Löfmark A. Implementation and student evaluation of clinical final examination in nursing education. Nurse Educ Today., [internet] 2013;33(12):15631568.

8. Furlong E, Fox P, Lavin M, Collins R. Oncology nursing students' views of a modified OSCE. Eur $J$ Oncol Nurs, [internet]. 2005;9(4):351-359.

9. Bedewy D, Gabriel A. The development and psychometric assessment of asscale to measure the severity of examination anxiety among undergraduate university students. Int J Educ Psychol., [internet] 2013;2(1):81104.

10. Yang RJ, Lu YY, Chung ML, Chang SF. Developing a short version of the test anxiety scale for baccalaureate nursing skills test - A preliminary study. Nurse Educ Pract., [internet] 2014;14(6):586-590.

11. Rush S, Ooms A, Marks-Maran D, Firth T. Students' perceptions of practice assessment in the skills laboratory: An evaluation study of oscas with immediate feedback. Nurse Educ Pract., [internet] 2014;14(6):627-634.

12. Oranye NO, Ahmad C, Ahmad N, Bakar RA. Assessing nursing clinical skills competence through objective structured clinical examination (OSCE) for open distance learning students in Open University Malaysia. Contemp Nurse., [internet] 2012;41(2):233-241. D

13. Shaddri I, Dharmayana IW, Sulian I. Penggunaan teknik guided imagery terhadap tingkat kecemasan siswa mengikuti aktivitas konseling kelompok. J Ilm BK Onsilia., [internet] 2018;1(3):68-78.

14. Prabu PK, Subhash J. Guided imagery therapy. IOSR J Nurs Heal Sci., [internet] 2015;4(5):56-58.

15. Apóstolo JLA, Kolcaba K. The effects of guided imagery on comfort, depression, anxiety, and stress of psychiatric inpatients with depressive disorders. Arch Psychiatr Nurs., [internet] 2009;23(6):403-411.

16. Nuwa MS, Kiik SM. Pengaruh spiritual guided imagery dan musik terhadap kecemasan pasien kanker yang menjalani 
kemoterapi. $J$ Ners dan kebidanan., [internet] 2020;7(1):095-106.

17. Kaur M, Thapar K, Saini P, Mishra. Effect of guided imagery on test anxiety among nursing. Int $J$ Dev Res., [internet] 2017;7(12):17409-17412.

18. Pietra J. Intervensi guided imagery untuk menurunkan kecemasan performa musikal pada siswa-siswi yang mengalami kecemasan performa musikal. J Psychol Sci Prof., [internet] 2019;3(2):83.

19. Aizid. Sehat dan cerdas dengan terapi musik: menyehatkan tubuh mencerdaskan otak. Laksana; 2011.

20. Hawari D. Manajemen stres cemas dan depresi. FK UI; 2013.

21. Musbikin I. Kehebatan musik untuk mengasah kecerdasan anak: mengenal cara kerja dan pengaruh musik untuk kehebatan anak anda. Power Books (Ihdina); 2009. 